\title{
Succinate dehydrogenase gene mutations are strongly associated with paraganglioma of the organ of Zuckerkandl
}

\author{
Maya B Lodish, Karen TAAdams ${ }^{1}$, Thanh T Huynh ${ }^{1}$, Tamara Prodanov ${ }^{1}$, \\ Alex Ling ${ }^{2}$, Clara Chen ${ }^{2}$, Suzanne Shusterman ${ }^{3}$, Camilo Jimenez, \\ Maria Merino ${ }^{5}$, Marybeth Hughes ${ }^{6}$, Kendall W Cradic ${ }^{7}$, Dragana Milosevic ${ }^{7}$, \\ Ravinder J Singh ${ }^{7}$, Constantine A Stratakis and Karel Pacak ${ }^{1}$
}

Section on Endocrinology and Genetics and Pediatric Endocrinology Program, Program on Developmental Endocrinology and Genetics (PDEGEN), National Institute of Child Health and Human Development (NICHD), National Institutes of Health (NIH), Building 10, CRC, 10 Center Drive, Room 1-3330, Bethesda, Maryland 20892, USA

${ }^{1}$ Reproductive Biology and Adult Endocrinology Program, NICHD, NIH, Bethesda, Maryland 20892, USA

${ }^{2}$ Department of Diagnostic Radiology, NIH, Warren Grant Magnuson Clinical Center, Bethesda, Maryland 20892, USA

${ }^{3}$ Department of Pediatric Oncology, Dana Farber Cancer Institute, Boston, Massachusetts 02115, USA

${ }^{4}$ The University of Texas M.D. Anderson Cancer Center, Houston, Texas 77030, USA

Departments of ${ }^{5}$ Pathology and ${ }^{6}$ Surgery, National Cancer Institute, NIH, Bethesda, Maryland 20892, USA

${ }^{7}$ Department of Laboratory Medicine and Pathology, Mayo Clinic, Rochester, Minnesota 55905, USA

(Correspondence should be addressed to K Pacak who is now at Section on Medical Neuroendocrinology, NICHD, NIH, Building 10 , CRC, Room 1E-3140, 10 Center Drive MSC-1109, Bethesda, Maryland 20892-1109, USA; Email: karel@ mail.nih.gov)

\begin{abstract}
Organ of Zuckerkandl paragangliomas (PGLs) are rare neuroendocrine tumors that are derived from chromaffin cells located around the origin of the inferior mesenteric artery extending to the level of the aortic bifurcation. Mutations in the genes encoding succinate dehydrogenase subunits $(\mathrm{SDH}) \mathrm{B}, \mathrm{C}$, and D (SDHx) have been associated with PGLs, but their contribution to PGLs of the organ of Zuckerkandl PGLs is not known. We aimed to describe the clinical presentation of patients with PGLs of the organ of Zuckerkandl and investigate the prevalence of SDHx mutations and other genetic defects among them. The clinical characteristics of 14 patients with PGL of the organ of Zuckerkandl were analyzed retrospectively; their DNA was tested for SDHx mutations and deletions. Eleven out of $14(79 \%)$ patients with PGLs of the organ of Zuckerkandl were found to have mutations in the SDHB (9) or $S D H D$ (2) genes; one patient was found to have the Carney-Stratakis syndrome (CSS), and his PGL was discovered during surgery for gastrointestinal stromal tumor. Our results show that $S D H x$ mutations are prevalent in pediatric and adult PGLs of the organ of Zuckerkandl. Patients with PGLs of the organ of Zuckerkandl should be screened for SDHx mutations and the CSS; in addition, asymptomatic carriers of an SDHx mutation among the relatives of affected patients may benefit from tumor screening for early PGL detection.
\end{abstract}

Endocrine-Related Cancer (2010) 17 581-588

\section{Introduction}

The organ of Zuckerkandl consists of extra-adrenal chromaffin cells located just below the origin of the inferior mesenteric artery and above the bifurcation of the aorta. This collection of paraganglia was first described by Hungarian anatomist and surgeon, Emil Zuckerkandl, who initially named them Nebenorgane (auxiliary organs; Ober 1983). The chromaffin cells that comprise the organ of Zuckerkandl originate from the same neural crest progenitor cells that give rise to the adrenal medulla. While these structures normally degenerate and involute by adolescence, small clusters of chromaffin cells remain that can serve as sites of future tumor development. At least 135 cases of paragangliomas (PGLs) of the organ of Zuckerkandl have been reported in the literature, but their association with specific mutations and/or genetic syndromes has not been described (Subramanian \& Maker 2006).

Germline mutations in the genes encoding subunits $\mathrm{B}, \mathrm{C}$, and D of succinate dehydrogenase $(\mathrm{SDH})$, the 
mitochondrial complex II, have been associated with the development of PGLs (Baysal et al. 2000, Astuti et al. 2001, 2003, Gimenez-Roqueplo et al. 2003, Brouwers et al. 2006, Ghayee et al. 2009). The SDHB, $S D H C$, and $S D H D$ genes encode mitochondrial proteins which serve as tumor suppressors, and lossof-function mutations in these genes are linked to formation of PGLs (Gottlieb \& Tomlinson 2005). The SDH enzyme is involved in cellular energy metabolism through the tricarboxylic acid cycle, the oxidative phosphorylation, and the electron transport chain (Gottlieb \& Tomlinson 2005). Although the mechanism that explains the link between mitochondrial dysfunction and tumor formation remains unknown, it is thought to be linked to an increase in reactive oxygen species and/or the activation of the hypoxia pathway or apoptosis (Eng et al. 2003, Gottlieb \& Tomlinson 2005, Benn \& Robinson 2006, Favier et al. 2009). The development of metastatic disease may be related to up-regulation of angiogenesis; however, the exact mechanism remains to be elucidated (Favier et al. 2002).

While an association with mutations in $S D H B$ and $S D H D$ genes has been found in patients with mediastinal PGLs, a specific analysis of $S D H$ mutations in patients with Zuckerkandl organ PGLs has not been performed to date. SDHD gene mutations are specifically associated with head and neck PGLs and much less frequently with malignant PGLs (Baysal et al. 2000, Benn et al. 2006, Havekes et al. 2007, Timmers et al. 2008). Mutations in the $S D H B$ gene are associated with a high rate of malignancy and aggressive disease; among patients with metastatic PGLs, the frequency of $S D H B$ mutations is between 30 and $83 \%$ (Gimenez-Roqueplo et al. 2003, Neumann et al. 2004, Amar et al. 2005, Brouwers et al. 2006). SDHB mutations have also been associated with shorter survival (Amar et al. 2007). Tumors classified as extra-adrenal abdominal PGLs (including a grouping of paraaortic/pericaval, bladder, remnants of the organ of Zuckerkandl, perirenal, retroperitoneal, and periadrenal) are associated with mutations in both $S D H B$ and SDHD genes (Benn et al. 2006). Anecdotal reports have described six patients with tumors of the organ of Zuckerkandl and SDHD (2) or $S D H B$ (4) mutations; however, to our knowledge this is the first series with a specific focus on tumors of this anatomic site (Gimenez-Roqueplo et al. 2003, Donahue et al. 2008).

From an initial observation of two patients with Zuckerkandl organ tumors who had SDHx mutations, we searched our clinical database for other patients with tumors involving this organ; we then tested the
DNA of these patients retrospectively for mutations in SDHx. Three of the patients had mutations in SDHx identified prior to their evaluation at our institution. In the present study we report in detail the clinical characteristics, biochemical phenotype, and clinical course of 14 patients with Zuckerkandl organ tumors seen at the National Institutes of Health (NIH) and the University of Texas M.D. Anderson Cancer Center over the past 20 years; in these patients, we examined the frequency of SDHx mutations.

\section{Materials and methods}

\section{Subjects of protocol}

Fourteen patients with primary PGLs of the organ of Zuckerkandl with a median age at diagnosis of 22.5 years (range 9-71) seen at the NIH, University of Texas M.D. Anderson Cancer Center and Dana-Farber Cancer Institute between 1989 and 2009 are presented in this study. A retrospective chart analysis was performed in order to identify patients with Zuckerkandl organ PGLs via review of abdominal computed tomography (CT) scans and analysis of operative and pathology reports. We reviewed radiological scans from all the cases and included only those tumors defined by the radiologist to be consistent with the specific anatomic localization of the Zuckerkandl organ. The patients were followed up for an average of 8 years. Initial patient symptoms, biochemical phenotype, details of primary tumor, and patient outcome were recorded. The presence of disease in sites where chromaffin cells are not normally present, i.e. disease in an extra-paraganglionic site (lymph nodes, bone, liver, and lung), was used to define metastatic disease as differentiated from multiple sites of disease (Gimenez-Roqueplo et al. 2008). Consent was obtained from each patient after full explanation of the purpose and nature of all procedures used. The investigation was approved by the NICHD IRB and the M.D. Anderson Cancer Center IRB.

\section{Genetic studies}

Three patients were known to harbor $S D H x$ mutations prior to their evaluation at the NIH. For those patients without prior studies, genetic testing of germline DNA for mutations in $S D H B, C$, and $D$ genes was performed. Blood samples for $S D H x$ mutation analysis were collected prospectively for purposes of genetic testing. Genomic DNA was extracted from whole blood as described previously. The four exons of $S D H D$, eight exons of $S D H B$, and six exons of $S D H C$ were amplified and sequenced by PCR based bidirectional sequencing 
by Mayo Medical Laboratories, Rochester, MN, USA or by the Division of Molecular Diagnostics at the University of Pittsburgh Medical Center, as described previously (Brouwers et al. 2006). Deletion testing was performed using a combination of multiplex ligationdependant probe amplification and Luminex FlexMap Technologies (Monico et al. 2007).

\section{Hormone assays}

Plasma catecholamines and metanephrines, and urinary catecholamines and metanephrines were measured using standard HPLC assays, as described previously, at the NIH Clinical Center and Mayo Medical Laboratories (Eisenhofer et al. 1986, Lenders et al. 1993).

\section{Results}

Patient characteristics are presented in Table 1. The median age of the nine males and five females at diagnosis was 22.5 years (range 9-71). Eleven out of $14(79 \%)$ patients with organ of Zuckerkandl PGLs were found to have mutations in the $S D H B$ (9) or $S D H D$ (2) genes. Four of these represent nonsense mutations, two missense mutations, two deletions, two frameshift and one splice site mutation. No mutations were found in three patients. Details of the mutations are presented in Table 1; two of the mutations represent novel mutations, $S D H B$ p.Arg38ProfsX40 and $S D H B$
Tyr61X, the remaining six are reported previously (Baysal et al. 2000, Brouwers et al. 2006, Timmers et al. 2007, Pasini et al. 2008, Solis et al. 2009). Three of the 14 patients had a first degree relative with a history of pheochromocytoma or PGL. None of the 14 patients were related to one another.

Eight out of $14(57 \%)$ patients had signs and symptoms related to catecholamine excess at the time of diagnosis. Results obtained from imaging studies used to detect tumor are presented in Table 1. In all 14 patients, CT scans were positive for visualization of Zuckerkandl organ tumor. ${ }^{123}$ I-metaiodobenzylguanidine $\left({ }^{123} \mathrm{I}-\mathrm{MIBG}\right)$ scans were able to detect tumors in eight out of nine cases, and $\mathrm{T} 2$ magnetic resonance imaging was positive in all eight patients in whom it was used. Four out of 14 (30\%) patients presented with the organ of Zuckerkandl PGL as their only primary tumor. While eight patients presented with metastatic disease, not all of these had the organ of Zuckerkandl PGL at the time of presentation. Seven out of 14 (50\%) patients who had organ of Zuckerkandl tumors as part of their initial presentation also had multiple primary tumors or metastatic disease at initial diagnosis. Two out of $14(14 \%)$ patients were identified to have the organ of Zuckerkandl PGL as an additional site of disease on long-term follow-up. One patient was diagnosed with the Carney-Stratakis syndrome (CSS) and was found to have the organ of Zuckerkandl PGL incidentally during surgery for gastrointestinal stromal tumor (GIST). The size of the organ of Zuckerkandl

Table 1 Patient characteristics

\begin{tabular}{|c|c|c|c|c|c|}
\hline Patient & Mutation & Biochemistry & $\begin{array}{l}\text { Size of } \\
\text { tumor }(\mathrm{cm})\end{array}$ & $\begin{array}{l}\text { Metastatic } \\
\text { at } \mathrm{dx} ?\end{array}$ & $\begin{array}{l}\text { Patient } \\
\text { outcome }\end{array}$ \\
\hline$M, 49$ & $S D H B$ p.Arg38Profs $X 40^{a}$ & U: NE, DA, NMN & 10 & Yes & AWD \\
\hline M,20 & Negative & Not done & 3.7 & No & NED \\
\hline $\mathrm{F}, 33$ & Negative & $\begin{array}{l}P: N E, C G A \\
U: N E, N M N\end{array}$ & 3.1 & Yes & DOD \\
\hline$M, 9$ & $S D H B$ p.Arg46X & $P:$ NMN & 14.5 & No & AWD \\
\hline $\mathrm{F}, 9$ & $S D H B$ first exon deletion & $P:$ NMN, NE, DA & 3 & Yes & AWD \\
\hline$M, 15$ & SDHB p.Arg46X & $\begin{array}{l}\text { U: NMN, NE, DA } \\
\text { P: NMN, NE }\end{array}$ & 3.5 & No & AWD \\
\hline$M, 34$ & $S D H B$ first exon deletion & $P: N E, N M N$ & 2.4 & Yes & AWD \\
\hline$F, 18$ & Negative & $P: N M N, C G A$ & 1.4 & Yes & AWD \\
\hline$F, 26$ & SDHD p.Arg38X & $P: N E$ & 6 & No & AWD \\
\hline$M, 24$ & SDHB Tyr61X ${ }^{a}$ & $\begin{array}{l}\text { P: NE } \\
\text { U: NE, NMN }\end{array}$ & 2.5 & No & AWD \\
\hline$M, 58$ & SDHB p.Trp200Cys & Not done & 6 & Yes & AWD \\
\hline $\mathrm{F}, 71$ & $S D H B$ IVS $1+1 \mathrm{G}>\mathrm{T}$ & $P:$ NMN, MN, NE, EPI & 10 & Yes & DOD \\
\hline$M, 21$ & SDHD p.Leu20CysfsX66 & $\mathrm{P}, \mathrm{U}: \mathrm{NE}, \mathrm{NMN}$ & 2 & Yes & AWD \\
\hline $\mathrm{M}, 11$ & SDHB p.Val140Phe & $\begin{array}{l}P: N E, N M N \\
U: N E, N M N\end{array}$ & 5.5 & No & AWD \\
\hline
\end{tabular}

P, plasma; U, urine; NE, norepinephrine; EPI, epinephrine; NMN, normetanephrine; CGA, chromogranin A; DA, dopamine; AWD, alive with disease; DOD, dead of disease; NED, no evidence of disease.

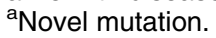




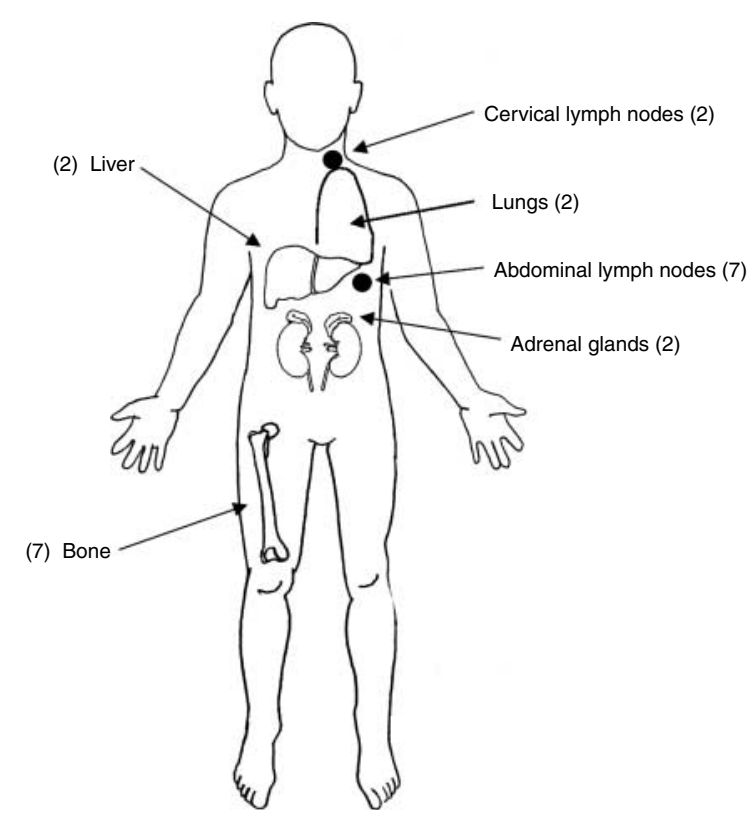

Figure 1 Sites of metastatic disease, $n=14$ patients.

PGLs was a mean of $5.3 \pm 3.8 \mathrm{~cm}$. Analysis of the biochemical data reveals that nine patients had a noradrenergic phenotype, and three had both noradrenergic and dopaminergic phenotypes (Table 1). Four patients developed metastatic disease during follow-up, the time to metastases ranged from 2 to 19 years $(6 \pm 8.7)$. Sites of metastatic disease and multiple sites of disease are presented in Fig. 1. Surgical resection of the primary tumor was performed in $11 / 14$ (79\%) of the patients, while four patients received therapeutic ${ }^{131}$ I-MIBG, two received octreotide therapy, four received conventional radiation therapy, three patients with aggressive and metastatic disease additionally received chemotherapy.

Images obtained through imaging studies and surgical images demonstrating the organ of Zuckerkandl PGLs are shown in Figs 2 and 3. Pathology of a representative patient's organ of Zuckerkandl PGL that is consistent with neuroendocrine tumor is presented in Fig. 4.

\section{Discussion}

The present study including 14 patients with PGLs of the organ of Zuckerkandl establishes for the first time an association of these tumors with $S D H B$ and $S D H D$ mutations. Our data also show that PGLs of the organ of Zuckerkandl are strongly associated with a noradrenergic phenotype and have an aggressive behavior, likely related to the $S D H B$ mutational status. The identification of $S D H x$ mutations in patients with the organ of Zuckerkandl PGLs has important implications for patient care and genetic screening of family members.

PGLs arise from sympathetic chromaffin tissue both in adrenal gland and outside of the adrenal gland in the abdomen or thorax, or alternatively originate from parasympathetic tissues in the head and neck (Benn et al. 2006). A particular grouping of PGLs, termed organ of Zuckerkandl PGLs, refer to a group of
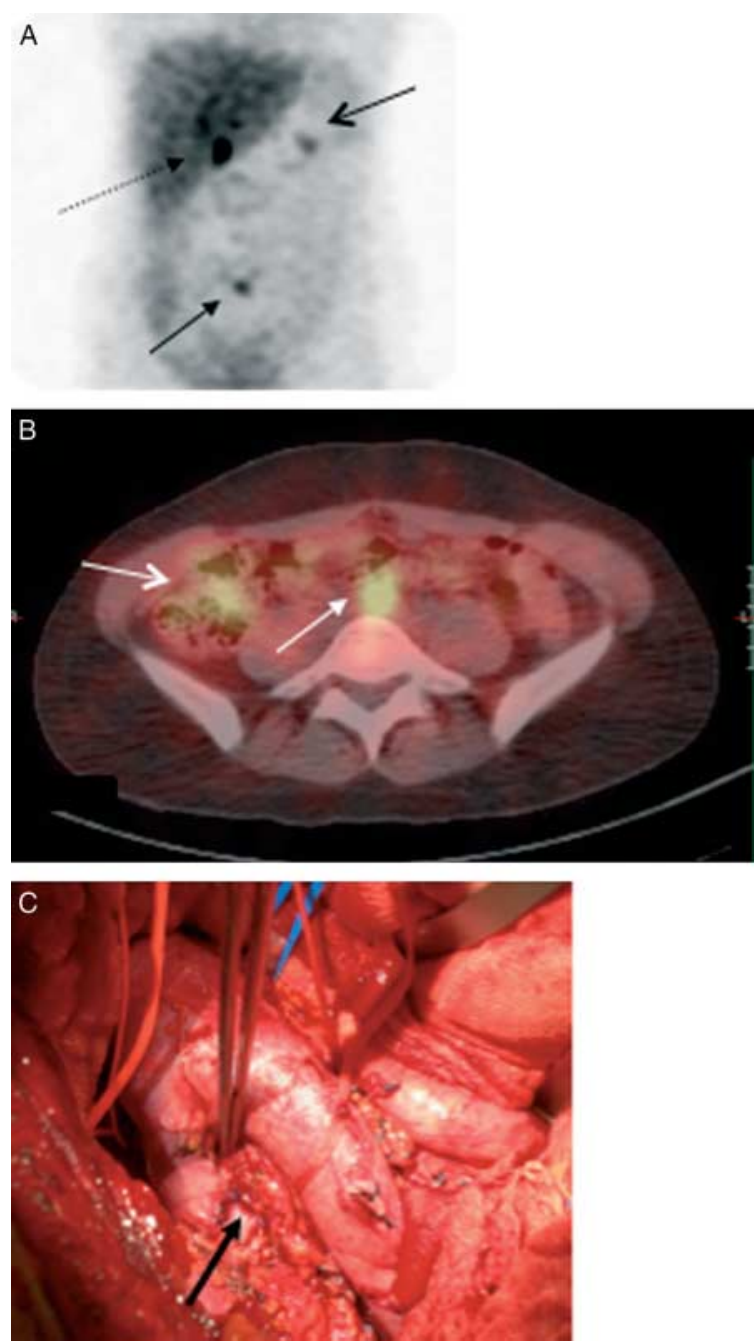

Figure 2 Diagnostic imaging from patient $F, 18$. (A) ${ }^{123}$ I-metaiodobenzylguanidine ( ${ }^{123}$ I-MIBG) anterior maximum intensity projection showing right adrenal mass (dashed arrow) and nodule anterior to vertebrae L5 representing the organ of Zuckerkandl tumor (closed arrow). There is a focus in the mid-portion of the left kidney (open arrow) thought to be due to activity retained in the collecting system. (B) Hybrid computed axial tomography (SPECT) and CT (SPECT/CT) ${ }^{123}$ I-MIBG with contrast of the abdomen showing a $2.6-\mathrm{cm}$ heterogeneously enhancing partially necrotic right adrenal mass (open arrow) and a 1.6-cm enhancing mass anterior to the spine and just inferior to the aortic bifurcation (closed arrow). (C) Surgical photo, arrow indicates the site of tumor below aortic bifurcation. 
extra-adrenal chromaffin tissue situated between the origin of the inferior mesenteric artery and the bifurcation of the aorta (Ober 1983). These PGLs are remnants of the primitive sympathetic nervous system. The function of the organ of Zuckerkandl is unknown in humans; however, it is thought to act as a chemoreceptor in other species (Hollinshead 1940). Mutations in genes encoding the SDH subunits B, C, and $\mathrm{D}$ of mitochondrial complex II have been associated with PGL development (Baysal et al. 2000, Astuti et al. 2001, 2003, Gimenez-Roqueplo et al. 2003, Brouwers et al. 2006, Ghayee et al. 2009). While most head and neck PGLs are associated with SDHD gene mutations, PGLs derived from the sympathetic nervous system are often related to $S D H B$ gene mutations. This is especially true for those deriving from extra-adrenal intra-abdominal lesions, which are frequently metastatic (Brouwers et al. 2006, Burnichon et al. 2009). Recently, mediastinal PGLs were also found to be strongly associated with mutations in SDHB gene (Ghayee et al. 2009).

While the majority of our patients had mutations in the SDHx genes, there are two important exceptions. One patient with primary adrenal pheochromocytoma as well as with organ of Zuckerkandl PGL who did not have a mutation in $S D H x$ also had congenital polycythemia. She was also tested (data not shown) for a mutation of the gene encoding the prolyl hydroxylase domain 2 protein, but she was found to be negative (Ladroue et al. 2008). Another patient who presented with a GIST and was incidentally found to have an organ of Zuckerkandl PGL at the time of surgery was also not found to have $S D H x$ mutation or deletion. Although most patients with CSS have SDHx mutations, up to $10 \%$ may harbor deletions that are not detectable by current screening methods (Carney \& Stratakis 2002, Pasini et al. 2008).

Testing for SDH subunits is now recommended for all cases of pheochromocytomas and PGLs, and testing should be offered to first-degree relatives for cancer surveillance and early detection (Neumann et al. 2002, Amar et al. 2005, Benn \& Robinson 2006, Jimenez et al. 2006, Prodanov et al. 2009). In addition, young patients with extra-adrenal pheochromocytomas should be tested for germline mutations of the von Hippel-Lindau (VHL) gene (Pacak et al. 2007, Boedeker et al. 2009). Germline mutations in the $S D H D$ and $S D H B$ genes should be considered a risk factor for PGLs of the organ of Zuckerkandl, and radiographic analysis of this area should be performed. However, exact surveillance recommendations for asymptomatic carriers of $S D H x$ mutations may vary between institutions (Benn \& Robinson 2006).
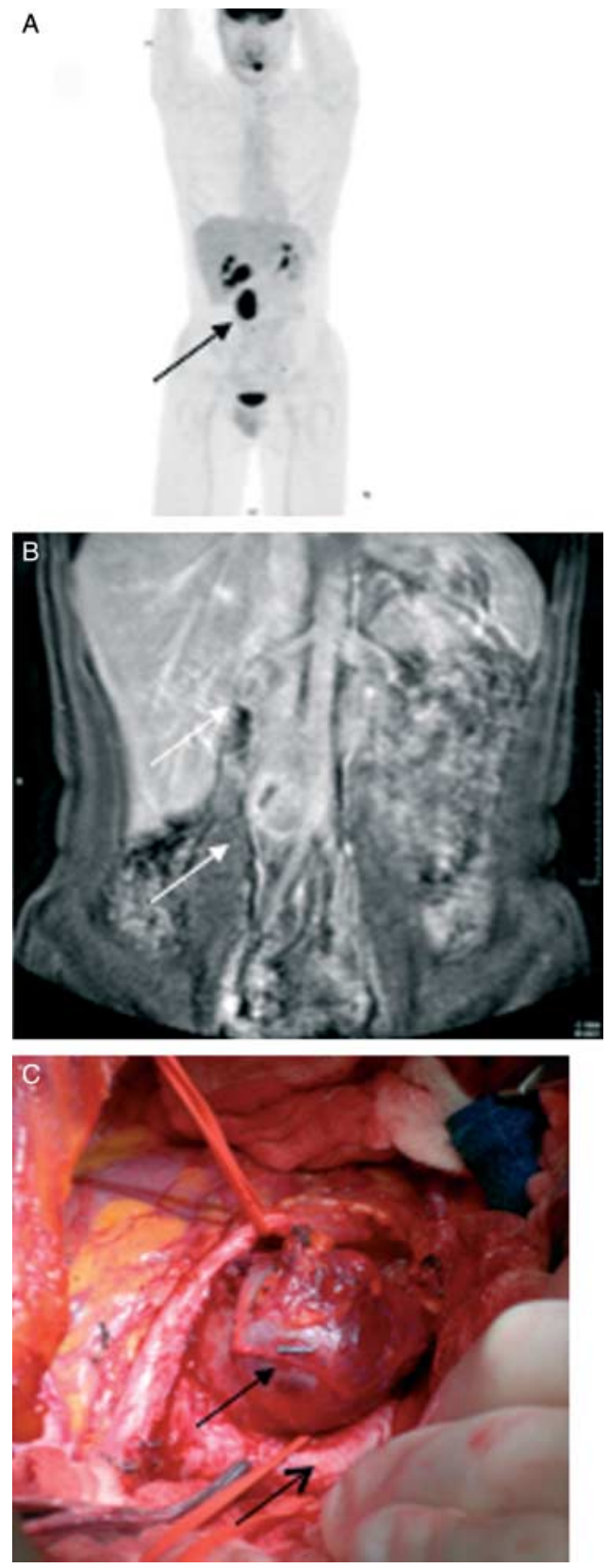

Figure 3 Diagnostic imaging from patient $M, 34$. (A)

$\left[{ }^{18} \mathrm{~F}\right]$-2-fluoro-deoxy-D-glucose (FDG PET/CT) demonstrates an enhancing retroperitoneal mass (closed arrow). (B) Magnetic resonance imaging $(\mathrm{MRI})$ anterior demonstrates two retroperitoneal masses, $4 \times 3$ and $4 \times 2 \mathrm{~cm}$ (closed arrows), one at the level of the right renal hilum and the other a periaortic mass between the abdominal aorta and the inferior vena cava. (C) Surgical photo demonstrating anatomical site of tumor (closed arrow) and the common iliac artery (open arrow).

Clinical presentation of pheochromocytomas and PGLs is variable depending on functionality of tumor; $70-80 \%$ of PGLs of the organ of Zuckerkandl are clinically functional (Subramanian \& Maker 2006). 

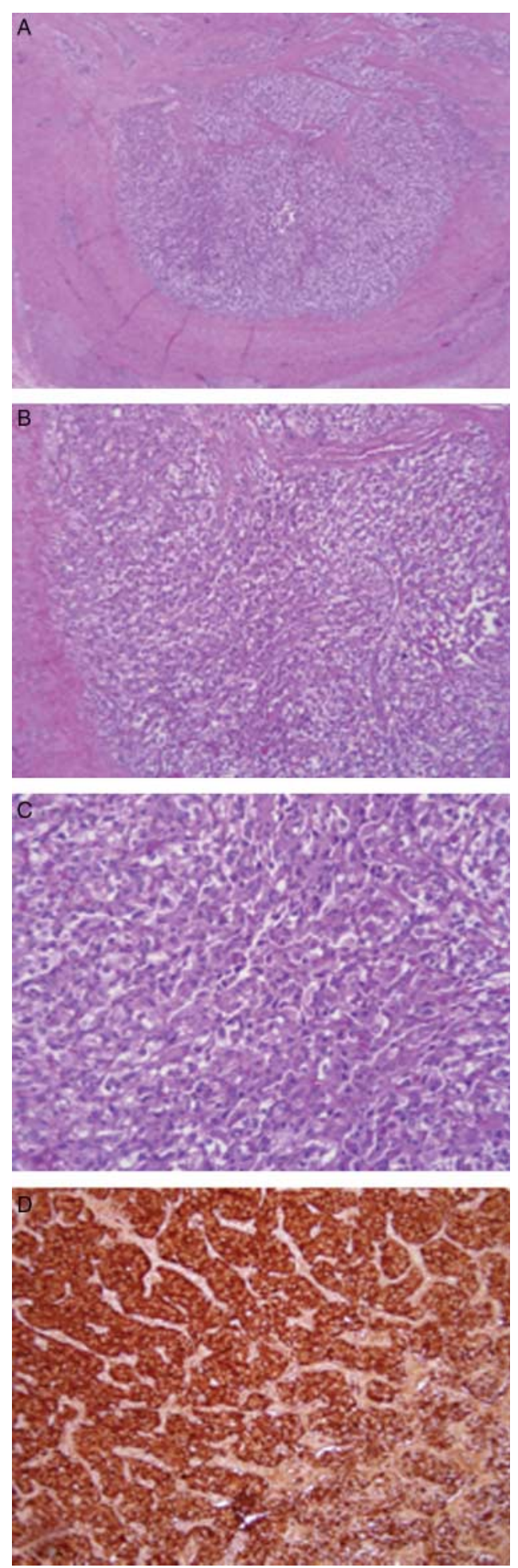

Figure 4 Low $4 \times(\mathrm{A})$, medium $10 \times(\mathrm{B})$, and high $40 \times(\mathrm{C})$ power magnification of $P G L$ cells in a representative patient. Immunohistochemistry for synaptophysin showing strong positivity of tumor cells (D).
Most extra-adrenal paraganglia as well as paraganglia in the setting of a $S D H B$ mutation primarily secrete norepinephrine or norepinephrine and dopamine, as they lack phenylethanolamine $N$-methyltransferase, the enzyme responsible for the conversion of norepinephrine to epinephrine (Timmers et al. 2007). Our patient group is consistent with this finding in the predominance of noradrenergic phenotype. Interestingly, three of our patients had tumors with mixed secretion of both norepinephrine and dopamine, all of whom had $S D H B$ mutations, consistent with previous studies linking this specific biochemical phenotype to the presence of $S D H B$ mutations (Timmers et al. 2007). Surgical resection is the preferred treatment for organ of Zuckerkandl PGLs; 11/14 of our patients underwent resection; however, a subset of patients presented with metastatic disease that was not amenable to resection. Similar to what is known about other extra-adrenal pheochromocytomas, organ of Zuckerkandl PGLs have a higher rate of malignancy than adrenal pheochromocytomas (Altergott et al. 1985). A review of 135 cases of organ of Zuckerkandl PGLs found that $41 \%$ of these tumors were malignant based on the presence of metastases and local invasion, with the most common sites of metastatic disease including bone, liver, and lungs (Subramanian \& Maker 2006). This finding is well supported by our data that shows that $86 \%$ of patients with organ of Zuckerkandl tumors had multiple sites of disease and/or metastatic disease.

We conclude that $S D H B$ and $S D H D$ mutations are indicators of possible organ of Zuckerkandl tumors and should lead to appropriate clinical studies and investigation of family members. This is also supported by our findings and previous findings that noradrenergic and dopaminergic phenotype in the same patient strongly suggest the presence of $S D H B$ gene mutation that should be addressed in planned genetic testing. As organ of Zuckerkandl PGLs are linked to SDHx-associated disease, having a PGL in the organ of Zuckerkandl impacts the probability of an $S D H B$ or $D$ mutations and warrants mutation testing.

\section{Declaration of interest}

The authors declare that there is no conflict of interest that could be perceived as prejudicing the impartiality of the research reported.

\section{Funding}

This work was supported by the Intramural Research funding of the Eunice Kennedy Shriver National Institute of Child Health and Human Development of the National Institutes of Health. 


\section{References}

Altergott R, Barbato A, Lawrence A, Paloyan E, Freeark RJ \& Prinz RA 1985 Spectrum of catecholamine-secreting tumors of the organ of Zuckerkandl. Surgery $\mathbf{9 8}$ 1121-1126.

Amar L, Bertherat J, Baudin E, Ajzenberg C, Bressac-de Paillerets B, Chabre O, Chamontin B, Delemer B, Giraud S, Murat A et al. 2005 Genetic testing in pheochromocytoma or functional paraganglioma. Journal of Clinical Oncology 23 8812-8818.

Amar L, Baudin E, Burnichon N, Peyrard S, Silvera S, Bertherat J, Bertagna X, Schlumberger M, Jeunemaitre X, Gimenez-Roqueplo AP et al. 2007 Succinate dehydrogenase B gene mutations predict survival in patients with malignant pheochromocytomas or paragangliomas. Journal of Clinical Endocrinology and Metabolism 92 3822-3828.

Astuti D, Latif F, Dallol A, Dahia PL, Douglas F, George E, Skoldberg F, Husebye ES, Eng C \& Maher ER 2001 Gene mutations in the succinate dehydrogenase subunit SDHB cause susceptibility to familial pheochromocytoma and to familial paraganglioma. American Journal of Human Genetics 69 49-54.

Astuti D, Hart-Holden N, Latif F, Lalloo F, Black GC, Lim C, Moran A, Grossman AB, Hodgson SV, Freemont A et al. 2003 Genetic analysis of mitochondrial complex II subunits SDHD, SDHB and SDHC in paraganglioma and phaeochromocytoma susceptibility. Clinical Endocrinology 59 728-733.

Baysal BE, Ferrell RE, Willett-Brozick JE, Lawrence EC, Myssiorek D, Bosch A, van der Mey A, Taschner PE, Rubinstein WS, Myers EN et al. 2000 Mutations in SDHD, a mitochondrial complex II gene, in hereditary paraganglioma. Science 287 848-851.

Benn DE \& Robinson BG 2006 Genetic basis of phaeochromocytoma and paraganglioma. Best Practice \& Research. Clinical Endocrinology \& Metabolism 20 435-450.

Benn DE, Gimenez-Roqueplo AP, Reilly JR, Bertherat J, Burgess J, Byth K, Croxson M, Dahia PL, Elston M, Gimm O et al. 2006 Clinical presentation and penetrance of pheochromocytoma/paraganglioma syndromes. Journal of Clinical Endocrinology and Metabolism 91 827-836.

Boedeker CC, Erlic Z, Richard S, Kontny U, GimenezRoqueplo AP, Cascon A, Robledo M, de Campos JM, van Nederveen FH, de Krijger RR et al. 2009 Head and neck paragangliomas in von Hippel-Lindau disease and multiple endocrine neoplasia type 2. Journal of Clinical Endocrinology and Metabolism 94 1938-1944.

Brouwers FM, Eisenhofer G, Tao JJ, Kant JA, Adams KT, Linehan WM \& Pacak K 2006 High frequency of SDHB germline mutations in patients with malignant catecholamine-producing paragangliomas: implications for genetic testing. Journal of Clinical Endocrinology and Metabolism 91 4505-4509.
Burnichon N, Rohmer V, Amar L, Herman P, Leboulleux S, Darrouzet V, Niccoli P, Gaillard D, Chabrier G, Chabolle F et al. 2009 The succinate dehydrogenase genetic testing in a large prospective series of patients with paragangliomas. Journal of Clinical Endocrinology and Metabolism 94 2817-2827.

Carney JA \& Stratakis CA 2002 Familial paraganglioma and gastric stromal sarcoma: a new syndrome distinct from the Carney triad. American Journal of Medical Genetics 108 132-139.

Donahue J, Sahani D, Tso L \& Cusack JC Jr 2008 Extraadrenal pheochromocytoma involving the organ of Zuckerkandl. Surgery 143 830-832.

Eisenhofer G, Goldstein DS, Stull R, Keiser HR, Sunderland T, Murphy DL \& Kopin IJ 1986 Simultaneous liquidchromatographic determination of 3,4-dihydroxyphenylglycol, catecholamines, and 3,4-dihydroxyphenylalanine in plasma, and their responses to inhibition of monoamine oxidase. Clinical Chemistry 32 2030-2033.

Eng C, Kiuru M, Fernandez MJ \& Aaltonen LA 2003 A role for mitochondrial enzymes in inherited neoplasia and beyond. Nature Reviews. Cancer 3 193-202.

Favier J, Plouin PF, Corvol P \& Gasc JM 2002 Angiogenesis and vascular architecture in pheochromocytomas: distinctive traits in malignant tumors. American Journal of Pathology 161 1235-1246.

Favier J, Briere JJ, Burnichon N, Riviere J, Vescovo L, Benit P, Giscos-Douriez I, De Reynies A, Bertherat J, Badoual C et al. 2009 The warburg effect is genetically determined in inherited pheochromocytomas. PLoS ONE 4 e7094.

Ghayee HK, Havekes B, Corssmit EP, Eisenhofer G, Hammes SR, Ahmad Z, Tessnow A, Lazurova I, Adams KT, Fojo AT et al. 2009 Mediastinal paragangliomas: association with mutations in the succinate dehydrogenase genes and aggressive behavior. Endocrine-Related Cancer 16 291-299.

Gimenez-Roqueplo AP, Favier J, Rustin P, Rieubland C, Crespin M, Nau V, Khau Van Kien P, Corvol P, Plouin PF \& Jeunemaitre X 2003 Mutations in the SDHB gene are associated with extra-adrenal and/or malignant phaeochromocytomas. Cancer Research 63 5615-5621.

Gimenez-Roqueplo AP, Burnichon N, Amar L, Favier J, Jeunemaitre X \& Plouin PF 2008 Recent advances in the genetics of phaeochromocytoma and functional paraganglioma. Clinical and Experimental Pharmacology and Physiology 35 376-379.

Gottlieb E \& Tomlinson IP 2005 Mitochondrial tumour suppressors: a genetic and biochemical update. Nature Reviews. Cancer 5 857-866.

Havekes B, Corssmit EP, Jansen JC, van der Mey AG, Vriends AH \& Romijn JA 2007 Malignant paragangliomas associated with mutations in the succinate dehydrogenase D gene. Journal of Clinical Endocrinology and Metabolism 92 1245-1248.

Hollinshead WH 1940 Chromaffin tissue and paraganglia. Quarterly Review of Biology 15 156-171. 
Jimenez C, Cote G, Arnold A \& Gagel RF 2006 Review: should patients with apparently sporadic pheochromocytomas or paragangliomas be screened for hereditary syndromes? Journal of Clinical Endocrinology and Metabolism 91 2851-2858.

Ladroue C, Carcenac R, Leporrier M, Gad S, Le Hello C, Galateau-Salle F, Feunteun J, Pouyssegur J, Richard S \& Gardie B 2008 PHD2 mutation and congenital erythrocytosis with paraganglioma. New England Journal of Medicine 359 2685-2692.

Lenders JW, Eisenhofer G, Armando I, Keiser HR, Goldstein DS \& Kopin IJ 1993 Determination of metanephrines in plasma by liquid chromatography with electrochemical detection. Clinical Chemistry 39 97-103.

Monico CG, Rossetti S, Schwanz HA, Olson JB, Lundquist PA, Dawson DB, Harris PC \& Milliner DS 2007 Comprehensive mutation screening in 55 probands with type 1 primary hyperoxaluria shows feasibility of a genebased diagnosis. Journal of the American Society of Nephrology 18 1905-1914.

Neumann HP, Bausch B, McWhinney SR, Bender BU, Gimm O, Franke G, Schipper J, Klisch J, Altehoefer C, Zerres K et al. 2002 Germ-line mutations in nonsyndromic pheochromocytoma. New England Journal of Medicine 346 1459-1466.

Neumann HP, Pawlu C, Peczkowska M, Bausch B, McWhinney SR, Muresan M, Buchta M, Franke G, Klisch J, Bley TA et al. 2004 Distinct clinical features of paraganglioma syndromes associated with SDHB and SDHD gene mutations. Journal of the American Medical Association 292 943-951.

Ober WB 1983 Emil Zuckerkandl and his delightful little organ. Pathology Annual 18 103-119.

Pacak K, Eisenhofer G, Ahlman H, Bornstein SR, GimenezRoqueplo AP, Grossman AB, Kimura N, Mannelli M, McNicol AM \& Tischler AS 2007 Pheochromocytoma: recommendations for clinical practice from the First International Symposium. October 2005. Nature Clinical Practice. Endocrinology \& Metabolism 3 92-102.

Pasini B, McWhinney SR, Bei T, Matyakhina L, Stergiopoulos S, Muchow M, Boikos SA, Ferrando B, Pacak K, Assie G et al. 2008 Clinical and molecular genetics of patients with the Carney-Stratakis syndrome and germline mutations of the genes coding for the succinate dehydrogenase subunits SDHB, SDHC, and SDHD. European Journal of Human Genetics 16 79-88.

Prodanov T, Havekes B, Nathanson KL, Adams KT \& Pacak K 2009 Malignant paraganglioma associated with succinate dehydrogenase subunit B in an 8-year-old child: the age of first screening? Pediatric Nephrology 24 1239-1242.

Solis DC, Burnichon N, Timmers HJ, Raygada MJ, Kozupa A, Merino MJ, Makey D, Adams KT, Venisse A, Gimenez-Roqueplo AP et al. 2009 Penetrance and clinical consequences of a gross SDHB deletion in a large family. Clinical Genetics 75 354-363.

Subramanian A \& Maker VK 2006 Organs of Zuckerkandl: their surgical significance and a review of a century of literature. American Journal of Surgery 192 224-234.

Timmers HJ, Kozupa A, Eisenhofer G, Raygada M, Adams KT, Solis D, Lenders JW \& Pacak K 2007 Clinical presentations, biochemical phenotypes, and genotypephenotype correlations in patients with succinate dehydrogenase subunit B-associated pheochromocytomas and paragangliomas. Journal of Clinical Endocrinology and Metabolism 92 779-786.

Timmers HJ, Pacak K, Bertherat J, Lenders JW, Duet M, Eisenhofer G, Stratakis CA, Niccoli-Sire P, Tran BH, Burnichon N et al. 2008 Mutations associated with succinate dehydrogenase D-related malignant paragangliomas. Clinical Endocrinology 68 561-566. 